Historic, Archive Document

Do not assume content reflects current scientific knowledge, policies, or practices. 



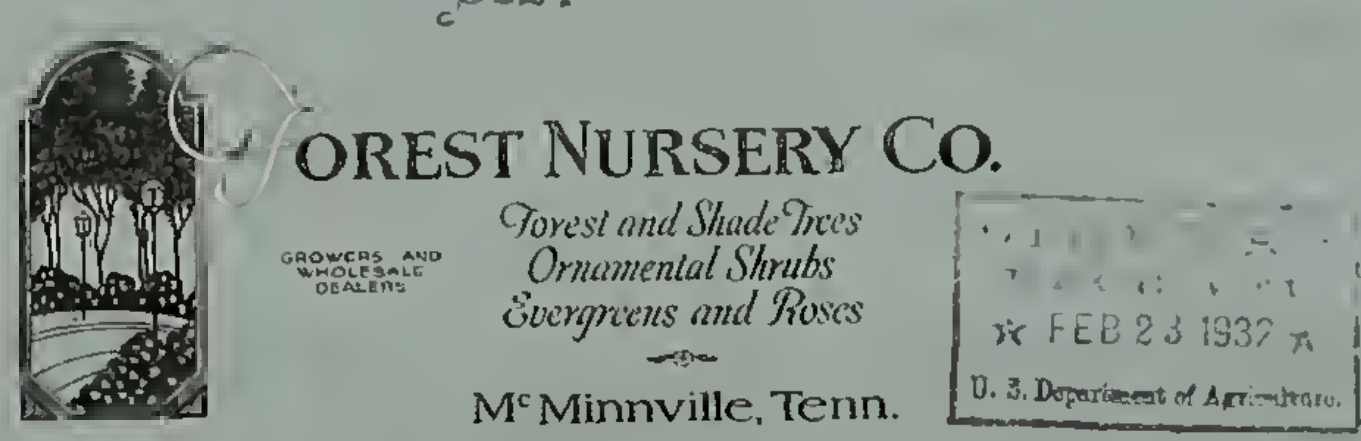

\section{...SPECIAL BARGAIN...}

\section{Wholesale Trade List No. 3.}

It is pessilute to make money on the stoch we list here at eluese low prises. Cover on your needs now hefore the spiug ussh. This is a list of high quality stoch al low prices.

Usual cerms ansl conditions. Boxing or baling al cost. No clarge for p.eking artand orders in bulk. All stock sold F. O.B. MicMinnville. Tennessec.

\section{SPECIAL CASH DISCOUNT}

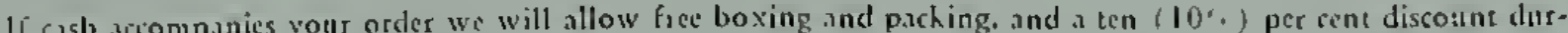

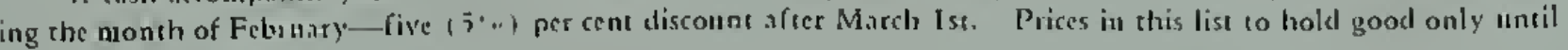
our Suring List Number $t$ is issucd.

Shipment can he made innediately or held for late spring as you nasy prefer. Send its your want list, we have m.ny varictics not here listed. Carlond orders solcited.

LWERGREEN

These prices inchide balling and burlippling.

Mamolivita. Amerlcan Occidentolis.

18 to 24 inch, well Illed

24 to 30 incli, well filled
30 to 36 incli, well tilled

IUREA CONSPICU, ALHORVTTAL.

18 to 24 inch
241030 incls

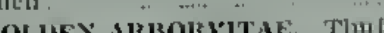

$$
\begin{aligned}
& 15 \text { to } 18 \text { inch } \\
& 18 \text { 10 } 2+\text { inct }
\end{aligned}
$$

241030 !nch

('IINESE: ALBORVITAE. Blota Orientalis.

24 to 30 luch, well tllled

310 t feel, well flute

+105 feel, well filled
LEgantissima irbokVtrat, Golden-lipped. 30 to 36 incl

l') T.u

24 to 30 snch
30 lo 36 incli

3 to $31 / 2 \mathrm{fect}$

MOSEDAIE ARHORVITAE

18 to 24 thehl....
2 to 3 fect

2 to 3 fect 181024 inch 30 to 36 inch spread
$3 B$ to 42 inch spiead

Jvilili HolizoNTaLAs. Creeping Jumper 18 to 24 inch
24 to 30 inch

JUNITER SABINA, SAVIn Junlpe 151018 juch
131024 inch

l'ICA EXCELSA. Notway Spruce. 181024 inch
310 icel

JiCEA RUBisa. Red Spruce.

18 to 24 inch

IITTNOSIORA O13TUSA, Hinokj Cypress. 18 to 24 linch
30 to 36 incli.

RETTNOSIOUA IISIFLARA

$$
\begin{aligned}
& 3 \text { to } 4 \text { feet } \\
& 4 \text { to } 5 \text { feet } \\
& 5 \text { to }
\end{aligned}
$$

IERINOSPORA PHUMOSA AUREA. GOlden

24 to 30 thcls
30 to 36 inch

metinospota l'Lumosa. Green Plume 30 to 36 inch

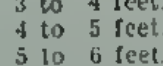

BISOADLEAF EVERGEENS

IThese prices include inlling and burlapping on all llems except ABELIA GRANDIILORA

15 to 18 Incl, 22-yr. (tri puddled_.... $\$ 1.25$ Per 10 Per 100 Per 1000

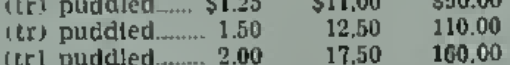
BUXUS St:MI'ERVIHE.S. Boxwood.

15 to 18 inch.........

IWUUS SUVFRTICOSA. Dwart Box. 6 to 8 inch...

Per 10 Per 100

VUONYIUS AAPONICA. Evergreen Euonymus.$$
18 \text { to } 24 \text { lnct }
$$

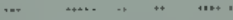

II.LX OPACA. American Holly.

15 to 18 inch ....... . .

18 to $24 \mathrm{lnc}$

lial.ma Latifolia. Mounlain Laurel.

to to 24 lnch nursery growi

2 to 3 teet. Col. Heavy Clump.

Lavroclarasus caltolina. Cherty Laurel.

24 to 30 inch.

30 to 36 inch
3 to 4 fect.

MAGNOLA GRANDILLORA

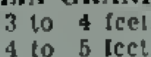

4 to
5 in

to is teel

80.00

RVIRGRLENS VOR LINING OIT.

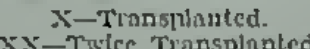

These Evergrechs for lining out are not dug with a ball of

Per 10 l'er 100 earth, but will be puddled as s0on as dug. They are well rooted,

$6.00 \quad 50.00$ gtad to send samples on request. Orders for these should

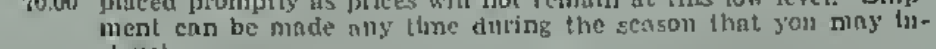

JUNII ER CHINENSIS. Clıthese Junlper.

$\quad 100 \quad 1,000$

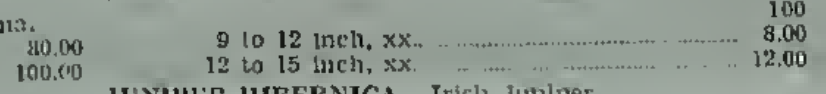

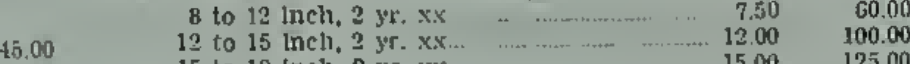

75,00
00.00

PICEA Cavinexis, white suruce. 9 to 12 inch, $2 \mathrm{yr}, \mathrm{xx}$
12 to 15 inch. $2 \mathrm{yr}, \mathrm{xx}$
15 to 18 inch.

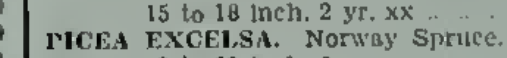
9 to 12 tnch, $2 \mathrm{yr}, \mathrm{xx}$ 5 to 18 Inch, 2 yr. $x$

r'ives Mrugilo. Mugho Plnc. 65 to 10 lnch $x \times$

PINUS NigRA. Altstrlon Plne. Nirira. Altstrin
12 to 18 incll $x x$

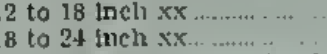

prous SYLVESTRIS. Scotch Pine 12 to 18 inell $x x$
18 to 24 inch $x x$

RETINOSRORA PLUMTOSA AURLA.

12 inch 2 yT. $x$

12 to 15 inch $2 \mathrm{yr}$. .xx.
15 to 18 inch 2 yr. xx

$\begin{array}{ll}6.00 & 50.00 \\ 8.01 & 70.00\end{array}$

6 to 8 inch $x x$. Canada liemlock.

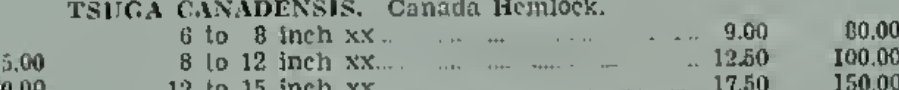
$\begin{array}{rrr}10000 \\ 15.50 & 10000\end{array}$

FAF LVERGREFNS

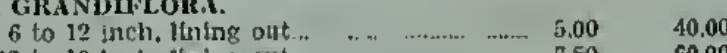

BUXUS SEMIPERVIRENS, Boxw'.................. T.50

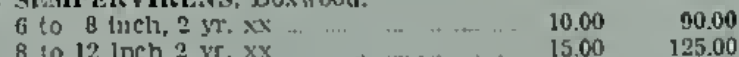

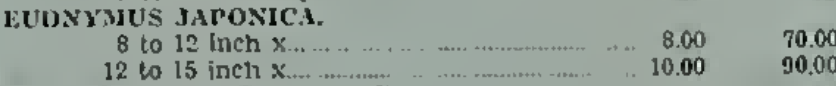

IEEX OPAC.A. American Holly. $\quad 7.00 \quad 6000$

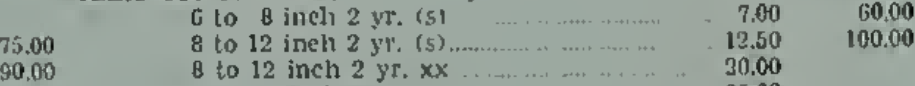

12 to 15 inch 2 yr. $x x$

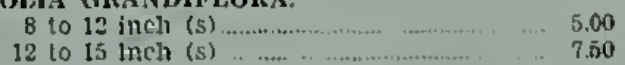

HARDY DECIDUDUS FLOWERING SIHULS, S-Seedings.
C-Rooicd Cinttings. $\mathrm{Tr}-$ Transplanted
Br-Branched

\section{ALTILA AiHLISSLIA. Double Rosy Red.} 12 to 18 Inch 2 Yr. (c) _ _.................... $\$ 1.25 \quad \$ 10.00$ 18 to 24 inch 2 yr. (c).....

12 to 18 Jnch (lr) $3 \mathrm{br}$. \& up

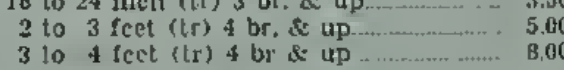

ALTREA ARDENS, PUIPle.

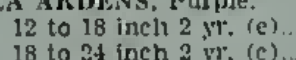

18 to 24 iach 2 yr: (c) ......... 12
18 to 24 inch (ir) 3 br \& up

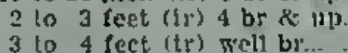

11.THEA BOULE DE FEU, DOUble Red. 12 to 18 Inch $23 \mathrm{yt}$ (e)

12 to 18 incls (tr) 3 br se up 18 to 29 inch (tr) 3 br sup 2 to 3 feet (tr) 4 br \& up

3 to 4 fcet (tr) well br... Dark Red, Double 18 to 24 inch $2 \mathrm{yr}$. (c). 12 to 18 inch (tri 3 br \& up
18 to 24 Infh (tr) 3 br \& up

MITIIEA JEANNE DF. ARC. PII'e Whitc, very Douls 12 lo 18 inels 2 yr. (c) 



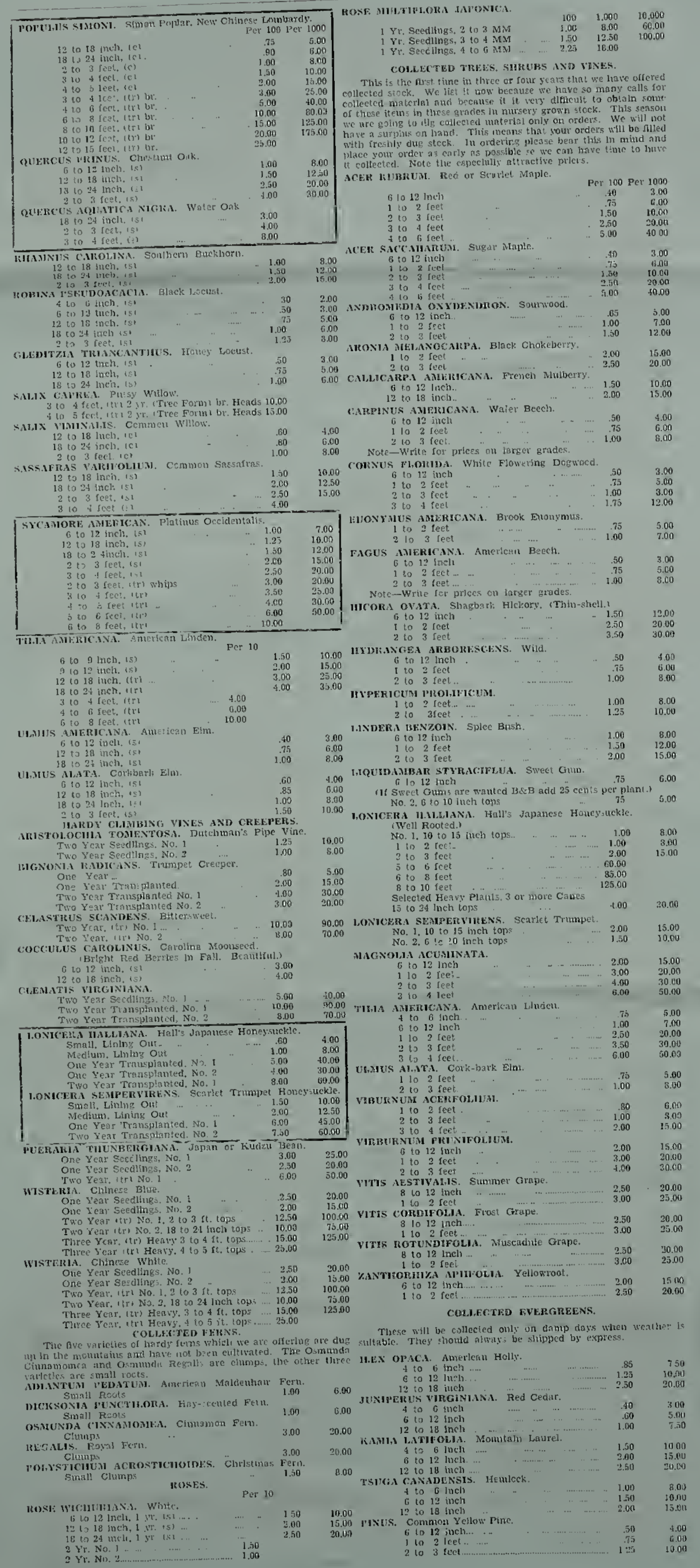

